\title{
Exploratory Study of Pedagogical Competence Among English Teachers in Junior High Schools in East Lombok Regency in Applying 2013 Curriculum-Based Learning Models
}

\author{
Untung Waluyo* \\ English Language Department \\ Universitas Mataram \\ NTB, Indonesia \\ untungwaluyo@unram.ac.id
}

\author{
Henny Soepriyanti \\ English Language Department \\ Universitas Mataram \\ NTB, Indonesia
}

\author{
Lalu Ali Wardana \\ English Language Department \\ Universitas Mataram \\ NTB, Indonesia
}

\begin{abstract}
The 2013 curriculum mandates that English teachers in junior high schools can use scientific approach learning models, such as Inquiry-based Learning, Project-based Learning, Discovery Learning and Problem-based Learning, through various learning activities in the classroom. To support this policy, the Ministry of Education and Culture has conducted a number of workshops and training initiatives to equip teachers with these learning models. Despite these efforts, research on the teacher's success story in applying the scientific approach has not much been done. With reference to this condition, this present study aims to reveal the pedagogical competence of English teachers in using the learning models recommended by the 2013 Curriculum and explore problems, challenges and obstacles faced by teachers in applying these learning models. This research was conducted in East Lombok Regency, NTB. The research subjects consisted of ten teachers from five selected schools. A descriptive-qualitative research design with a multicase study approach was used to uncover the phenomenon being investigated. Data collection was done through interviews, classroom observations and document studies. The data were analyzed by using a thematic analysis approach. Results of the study show that teachers developed divergent pedagogical competencies in applying the suggested learning models. Among other factors, ineffective teacher professional development training was identified as the cause of the emerging problems, challenges and obstacles that hinder the optimization of their pedagogical competencies.
\end{abstract}

Keywords - 2013 curriculum, scientific approach, inquiry-based learning, discovery learning, project-based learning, problembased learning

\section{INTRODUCTION}

According to the Law No. 20 of 2003, Article 1 [1], the curriculum is defined as a set of plans and regulations regarding the objectives, content and learning materials and methods used as guidelines for carrying out learning activities to achieve the educational goals provided. The definition implies that the curriculum was developed by the government as a guide for teachers to design teaching materials, make lesson plans, deliver material to students and evaluate their learning outcomes. In other words, the curriculum is a set of thoughts, actions, and objectives of the education system [2].
Furthermore, the Law on Education No. 20 of 2003 stipulates that teachers are professionals who carry out the task of carrying out the mandate of national education goals through a series of pedagogical activities so that the potential of learners develops to the maximum. With the advancement of the world of education, the task of the teacher as an educator as well as a teacher becomes increasingly heavy. They are not only required to carry out their duties professionally, but also must have professional knowledge and teaching skills. Thus, they must be able and always ready to face any changes and developments in the world of education. As the learning system changes, teachers must be able to continuously arouse awareness of thinking, develop a disciplined attitude, be creative, innovative, and be committed to their assignments.

In connection with the above issue, the English language curriculum in Indonesia has changed from time to time. At present, the official curriculum issued by the Indonesian government is the 2013 Curriculum. This curriculum has been adopted by schools throughout Indonesia. Unlike the previous curriculum, the latest curriculum is currently being developed with an emphasis on achieving student competence in gaining language experience not only in the classroom but also in the social environment of the students through the use of a scientific learning approach. Through this approach, teachers are expected to create a systematic teaching and learning process through critical thinking activities. By using this approach, students are expected to be able to critically explore the power of their reasoning and curiosity through the steps of a scientific approach.

Related to the learning model, the 2013 Curriculum mandates that English teachers at the Junior High School level are required to be able to use a scientific approach through various learning models such as Inquiry-based Learning, Discovery-based Learning, Project-based Learning and Problem-based Learning. The use of this approach aims to encourage students to be more critical and take the initiative in participating in class. The use of such learning models will certainly make teaching and learning activities in the classroom come alive because the teacher is presumably able to create new innovations in carrying out teaching and learning activities. Through this 
approach, teachers are expected to be able to encourage students to learn more independently.

Judging from the suggested learning approaches and models, the development of the 2013 curriculum follows the paradigm of Social Constructivism Theory. This theory simply explains that the formation of active knowledge in every learner is obtained through their participation in the context of their social life [3]. According to Social Constructivism theory, the meaning of an action is built on consensus among those involved in interaction. Thus, social constructivism in this context can mean the use of individual social contexts to construct meaning in accordance with their individual knowledge.

Based on the theoretical principles above, the approaches and models of scientific learning in the 2013 Curriculum are designed by prioritizing individual collaboration to create a social environment and construct meaning making according to their level of knowledge. This collaboration activity is used by each student to create shared meanings and broaden their knowledge about the aspects of life they learn [4]. This theory is in line with the principles of a scientific approach and collaborative learning models that prioritize collaborative work and critical thinking.

Apart from the ideal conditions above, a number of research reports under the 2013 Curriculum theme show that the conditions of teaching English with a scientific approach are still far from the expectation. According to Jaedun, Hariyanto \& Nuryadin [5] English teachers face many obstacles in applying the scientific approach. In addition to their inadequate knowledge, they also have limited skills in applying scientific approaches. Therefore, in general, students' participation in the classroom is relatively low. Although teachers have participated in various professional educational and training programs, the results show that they do not change so much. In many instances, teachers reverted to using an old-fashioned approach that employs one-way communication because of their lacked pedagogical competencies.

The term pedagogical competence is clearly explained in detail in Minister of National Education Regulation No. 16 of 2007 concerning Teacher Competency Standards [6]. A teacher is said to master good pedagogical competence if he (1) masters learning theory; (2) mastering educational theory; (3) mastery of skills in developing curriculum subjects taught; (4) have skills for learning; (5) communicating effectively, empathically, and politely with learning; (6) regulates assessment and evaluation for the process and learning outcomes; and (7) contemplating improving the quality of lessons. In this study, researchers used the 7 indicators as a lens to explain the observed phenomenon.

In a qualitative study, Murdadi \& Sulastri [7] reported that teacher competence positively influenced student achievement. The researchers also reported that teachers still taught students monotonously and this apparently affected the students' motivation to participate in the classroom. The study concludes that the teacher has not mastered pedagogical competency standards and basic competencies of subjects who cannot apply the scientific approach optimally. They have not yet been able to develop learning material creatively so they still use the old teaching method. In the same vein, Azizah, Widodo \& Adriana [8] reported that teachers faced various difficulties in implementing the 2013 Curriculum because of their low morale and pedagogical competences.

Normatively, the 2013 Curriculum book states that English teachers at the junior high level are expected to be able to use a scientific approach through various learning models, such as discovery learning, project-based learning, problem-based learning, and the like. The use of this approach aims to encourage students to be more critical and able to take initiative and participate in class. The use of such learning models will certainly make teaching and learning activities in the classroom livelier because the teacher is able to create new innovations in carrying out teaching and learning activities. Through this approach, teachers are expected to be able to encourage students to learn more independently.

However, so far the facts in the field show the opposite. A number of research results related to the implementation of the 2013 Curriculum report that English teachers from several regions in Indonesia had difficulties to implement the 2013 Curriculum [9, 10]. In general they have difficulties in understanding and applying the new concepts - such as approaches, learning models and ways of evaluating - recommended by the 2013 Curriculum. The difficulties related to the way of assessing learning outcomes are also reported by Retnawati, Hadi, and Nugraha [11]. All of the above problems arise as a result of teachers' lack knowledge and skills about the 2013 Curriculum. This unavoidably triggers the emergence of confusion and diverse responses of the teachers in implementing the 2013 Curriculum.

Still related to the teacher's problem in responding to the 2013 Curriculum, Sahdiati [11] reported that teachers generally had difficulty in developing teaching steps when using a scientific approach. This report is in line with the results of Darsih's research [12] which states that teachers encountered a number of problems in applying the 2013 Curriculum because they were not familiar with new learning models and how to develop assessment rubrics to measure student competencies. The emergence of this problem is closely related to their lack of understanding of scientific approaches. Thus far, a number of studies in Indonesia revealed sporadically about similar problems, but this area of research did not specifically address the issue of the teacher's pedagogical ability to apply a scientific approach. With reference to the results of the literature study, this research is deemed necessary to be carried out.

With reference to the problems above, the general aim of the current study is to reveal the level of pedagogical competence of English teachers in East Lombok Regency in applying the learning models recommended by the 2013 Curriculum. The issue of teacher pedagogical competence becomes obviously important because it is closely related to teacher strategies in overcoming challenges in their daily professional life. Specifically, this study aims to answer the following questions: (1) what is the level of pedagogical competence of English teachers in Junior High Schools in East Lombok Regency in applying learning 
models in the 2013 Curriculum? (2) What problems, obstacles and difficulties do teachers face in applying learning models to the 2013 Curriculum? (3) What lesson learned can be taken from the current study?

\section{METHOD}

This study aims to (1) reveal the level of pedagogical competence of English Teachers in Junior High Schools in East Lombok Regency in applying learning models in the 2013 Curriculum, (2) identify problems, obstacles and difficulties faced by teachers in applying the learning models suggested by the 2013 Curriculum and (3) gather the lesson-learned from teachers' efforts in responding to the demands of the 2013 curriculum. Sampling was conducted purposively for this study. Purposive sampling is widely used technique in qualitative research to get qualitative rich data [14]. In this activity the researchers identified and selected individuals or groups of individuals who specifically had knowledge or experience with interesting phenomena. Thus, by using purposive sampling, it was expected that the sample criteria could be adjusted to the research needs.

This qualitative research data of the current study was obtained through a number of activities in the field such as in-depth interviews, focus group discussions, observations, and document studies. For the purpose of in-depth interviews, the researchers conducted interviews with teachers and principals to obtain primary data on various issues related to the use of scientific approaches and collaborative learning models. Researchers also held focused group discussions with teachers in schools to reveal data that did not appear from in-depth interviews. Next, to check the consistency of the data, the researcher conducted observations about the way the teacher did the teaching activities in the classroom. The way the teacher used collaborative learning models in the classroom was observed in detail. Prior to obtaining the data of observation, researchers requested permission to the school management to carry out observations. These observations were used to account for how teachers applied collaborative learning models in schools.

The study employed a descriptive-qualitative research design with a multi-case study approach. From a number of 5 research sites, data were collected, analyzed and compared. The design of this study was chosen to compare the problems experienced by the teachers participating in this study. It was expected that the results of this study could reveal the problems, challenges and obstacles of teaching English related to the application of collaborative learning models.

As regards data analysis, all of the research data obtained from observations interviews and document studies were analyzed in several stages. In the first stage, the researchers wrote interview transcripts in a verbatim form. Upon the completion of the data transcription, the researchers grouped the data based on themes that emerged from conversations with informants. Further, the researchers put the data into the themes based on categories of responses made by the participants. Finally, the data obtained from observations and document studies were transcribed and grouped into a number of themes that matched with the data themes received from various sources. All of the data from various sources were further analyzed using the analysis phases as suggested by Miles and Huberman [15]. This included data reduction activities, data presentation, and drawing conclusions and verification. The results were then further summarized and labeled in accordance with the emerging theme. All of the data obtained were then reread, coded and grouped according to the categories or themes that emerge from the data. The results were then summarized further and labelled with themes

\section{FINDINGS AND DISCUSSION}

The results of this study revealed two important findings that emerged from interviews with participants regarding the level of teacher's pedagogical knowledge. The first problem is the lack of teacher skills in developing teaching materials based on the 2013 Curriculum. In general, participants stated that they still used textbooks from the previous curriculum. This situation indirectly affected the way they delivered the learning materials in the classroom. Indeed, some of them had attended a number of workshops on 2013 Curriculum. However, they admitted that the workshop activities did not much focus on how to facilitate learning engagement with students. This explains why the delivery of the English lessons was still dominantly focused on teachers' talks, which was certainly not in accordance with the demands of the new curriculum.

The second problem was related to teachers' limited access to the training programs on the socialization of 2013 Curriculum provided by both district and provincial education authorities. Participants revealed that due to their lack of knowledge of 2013 Curriculum, they did not have the courage to try out new teaching skills that were disseminated by their colleagues who returned from 2013 Curriculum training. Teacher 07, stated, "In our school only a few teachers attended the 2013 Curriculum workshop and training activities in Selong (city). After returning from the training they shared information but we did not fully understand. We were taught how to assess student behavior based on Basic Competence 1 and Basic Competence 2 but we are still unfamiliar with the teaching approaches" The same thing was revealed by Teacher-08. "Because of our limited knowledge, we administer assessment the best to our knowledge. This 2013 Curriculum assessment is indeed very complicated and confusing" Because the understanding of 2013 Curriculum was inadequate, many teachers did the assessment as what it was. For this reason, they hope that the authorities give them more opportunities to attend trainings that focus on how to improve the quality of teaching, develop scientific inquiry-based learning models and the 2013 Curriculumbased assessment models.

Still dealing with the same issue, Teacher-05 explained, "I have tried to apply teaching methods that focus on student group work, but sometimes I am still dominant in explaining rather than letting students work together" Teacher-10 shared the same opinion. For him, it was difficult to present English teaching materials in innovative and creative ways through various inquiry-based activities because their knowledge and pedagogical skills were still 
very inadequate. In the same vein, Teacher-04 explained, "I have difficulty in developing English teaching skills because I have never participated in 2013 Curriculum training and the school supervisor never demonstrated us how to teach English with a new approach model. He just checked our administrative preparation" These quotes provide evidence that teachers indeed lacked pedagogical knowledge on 2013 Curriculum due to the absence of adequate training. They are actually enthusiastic to learn new ways of teaching English that are interactive and innovative, but they rarely and almost never receive the opportunity to attend training on 2013 Curriculum.

Observations in a number of classrooms show the same thing. For example, Teacher-09 still seemed to maintain an old-fashioned approach to teaching. Although in interviews he claimed to have tried a scientific approach, in practice he was still dominant using a learning process that focused on teacher's explanations. Observations in a number of classrooms showed similar things. With regard to the problem of applying the scientific approach as mandated by the 2013 Curriculum, a number of teachers stated that they lacked knowledge of the new approach. They claimed they were not confident to implement the new approach model. Most of the participants explained that they were still conditioned to use teaching and learning activities that focused on the teacher rather than the students. For example Teacher-01 commented, "I have tried to change my teaching methods by focusing on student activities but I am still experiencing difficulties. Even though I have participated in several 2013 Curriculum trainings, that doesn't solve my problem"

In the same case Teacher-03 believed that it was difficult for him to present learning material with a projectbased learning or problem-based learning model because their knowledge of the new method was still very limited. Teacher-06 found that his teaching partners faced the same problem with new learning models. In the same vein, Teacher-04 argues, "I have difficulty developing a scientific approach to teaching English because I do not fully understand the 2013 Curriculum. The curriculum training for teachers in our area is almost none and the implementation is not sustainable" Similarly, a number of teachers explained that they got a complete lesson plan from the instructor but they did not fully understand the steps of teaching them to students.

From the above quotations it can be concluded that the top-down teacher professional development training provides less practical benefits for the development of their pedagogical knowledge. According to a number of teachers, this problem persistently occurred because there was no clear direction and technical guidance from the relevant agencies after the implementation of the 2013 Curriculum training and socialization was done. Teachers must be satisfied with what they know. This explains their reason why they delivered the 2013 Curriculum in their own way.

Data from observations and interviews indicate that there were two main findings that explain why teachers are still using the old patterns of teaching model: (1) the teacher's lack of understanding of the contents of 2013 Curriculum, and (2) weak teacher's pedagogical knowledge of learning models that employ a scientific approach. Most participants agreed that they were still confused by how to implement the new approach. The researchers assume that the problem above occurs because the teacher is not well equipped with the learning models mandated by 2013 Curriculum. As such, they do not know how to encourage students to learn through the process of inquiry and discovery.

In line with the teacher's response, most school principals explained that because 2013 Curriculum was a 'new item', of course there were still many shortcomings in its implementation. Despite the shortcomings of 2013 Curriculum, almost all school principals interviewed indicated that they fully supported the 2013 Curriculum policy issued by the central government. For example, KS05 commented, "In principle, we support what has become a national government policy. We facilitate what is needed by the government to advance education in our place" A similar explanation was expressed by a number of school principals who participated in this study. KS-02 stated, "I have just been placed in this school. Therefore, I must be prepared to carry out the mandate from the government". In the same vein KS-03 emphasized, "I must follow what my institution has outlined because I am on duty here" Normative statements made by these principals indicate their compliance with government policies. Although most of them were aware of the problems faced by the teachers, they could not do their maximum efforts because of the lack of government support, especially the local government of East Lombok Regency. Therefore, the majority of school principals were still in a 'wait and see' state, hoping that the government would immediately intensify the training on 2013 Curriculum.

Going through all the previous paragraphs, the lessons learned that can be drawn from the findings of this study are stated as follows: (a) there was an immediate need for collaboration between schools and professional training providers to disseminate the 2013 Curriculum through the on-going professional development; (b) it is necessary for every school to establish a post-training learning community for training alumni so that the information sharing process could be facilitated; (c) the 2013 Curriculum training material should be carried out in a balanced manner both theoretically and practically and teachers should be given opportunities to try out scientific approaches. Thus, they are more directed towards the use of diverse learning models such as discovery learning, problem-based learning, project-based learning, and so on. By providing such training, teachers would feel ready to carry out the mandate of 2013 Curriculum.

Before you begin to format your paper, first write and save the content as a separate text file. Complete all content and organizational editing before formatting. Please note sections A-D below for more information on proofreading, spelling and grammar. Keep your text and graphic files separate until after the text has been formatted and styled. Do not use hard tabs, and limit use of hard returns to only one return at the end of a paragraph. Do not add any kind of pagination anywhere in the paper. Do not number text heads-the template will do that for you. 


\section{CONCLUSION}

The results of this study indicate that the implementation of 2013 Curriculum in the field is still experiencing serious problems. First, due to the lack of clear information from the government about the 2013 Curriculum, teachers' pedagogical knowledge and skills did not develop well in implementing the new curriculum. Problems, challenges and obstacles faced by teachers, among others, are the dominant mindset and old teaching patterns, the lack of teacher professional training directed at mastering theories and practices related to the 2013 Curriculum and the lack of support from school principals in the implementation of the Curriculum. This paper concludes that the government, as a 2013 Curriculum policy maker, should evaluate the implementation of 2013 Curriculum nationally. Thus, a real picture of the 2013 Curriculum implementation problems faced by teachers in schools throughout Indonesia will be obtained.

\section{ACKNOWLEDGEMENT}

The researchers would like to express their gratitude to the Rector of Universitas Mataram and Chairman of the Research Center who had provided a research grant through a DIPA 2019.

\section{REFERENCES}

1] Nomor, P. M. P. N. (16). Tahun 2007 tentang standar kualifikasi akademik dan kompetensi guru. Jakarta: Depdiknas.

[2] W. Null. Curriculum: from theory to practice. Maryland: Rowman \& Littlefield Publishers, Inc, 2011

[3] C. Beck, \& C. M. Kosnik. Innovations in teacher education: A social constructivist approach. Albany: State University of New York Press. 2006

[4] F. Brownlie, \& L. Schnellert.. It's all about thinking: Collaborating to support all learners, in English, social studies, and humanities. Winnipeg: Portage \& Main Press. 2009

[5] J. Jaedun, L. Hariyanto, E.R. Nuryadin, E.R. An evaluation of the implementation of Curriculum 2013 at the building construction department of vocational high schools in
Yogyakarta. Journal of Education. 7(1), 2014, pp. 14-22. Available https://journal.uny.ac.id/index.php/joe/article/view/5757

[6] UU No. 20 tahun 2003. (The Law No. 20 of 2003). Available at https://kelembagaan.ristekdikti.go.id/wpcontent/uploads/2016/08/UU_no_20_th_2003.pdf

[7] I.S. Murdadi, \& E. Sulastri. The Impact of Certification on the Enhancement of Teachers' Professional Competence at SMK Pelita Salatiga (Dampak Sertifikasi Guru dalam Peningkatan Kompetensi Profesional di Kalangan Guru SMK Pelita Salatiga). National Seminar Proceeding, 2018. Retrieved from http://eprints.uny.ac.id/21962/1/58\%20Imanuel\%20Sri\%20M urdadi $\% 20 \% 26 \% 20$ Entri\%20Sulistari.pdf'

[8] S. Azizah, A. Widodo, A. \& I. Adriana. Implementasi Pendekatan Scientific dalam Pengajaran Bahasa Inggris Kurikulum 2013 di SMPN 1 Pamekasan. OKARA, Vol. 2, Tahun X, Nopember 2015, pp. 296-315.

[9] Y.N. Ekawati. The Implementation of Curriculum 2013: A Case Study of English Teachers' Experience at SMA Lab School in Indonesia. ELLD Journal, 7 (1), 2016. Pp. 84-90. Available http://digilib.uinsgd.ac.id/4531/2/C7\%20YULIA\%20NE.pdf

[10] Y. N. Ekawati.. English teachers' problems in applying the 2013 curriculum. English Review: Journal of English Education, 6(1), 2017, pp 41-48. DOI: 10.25134/erjee.v6i1.769.

[11] H. Retnawati, S. Hadi, and A.C. Nugraha. Vocational High School Teachers Difficulties in Implementing the Assessment in 2013 Curriculum in Yogyakarta Province of Indonesia. International Journal of Instruction Vol. 9 No.1, 2016, pp. $33-48$

[12] A. Sahdiati. Teachers Challenges in Implementing Dual Curriculum "Curriculum 2006 and 2013 Curriculum. Skripsi (thesis), Universitas Mataram. 2015

[13] A. Darsih, Understanding the 2013 Curriculum of English Teaching through the Teachers' and Policymakers' Perspectives. International Journal of Enhanced Research in Educational Development (IJERED), ISSN: 2320-8708, 2014

[14] M. A. Patton. Qualitative Research \& Evaluation Methods (3rd ed.). Thousand Oaks, California: Sage Publications, 2002

[15] M. B., Miles \& A,M. Huberman, A. M. Qualitative data analysis (4th Ed.). Thousand Oaks, CA: Sage Publications, 2014 